Research Article

\title{
Involvements of food grade dialdehydic pectin as cross-linker and soy protein as additive in the production of MNP-CLEA-lipase from Hevea brasiliensis
}

\begin{abstract}
Skim latex from Hevea brasiliensis (rubber tree) contains many useful enzymes that can be utilized to produce value-added products. Lipase recovered from skim latex serum was immobilized via cross-linked enzyme aggregates (CLEA) technology, while supported by magnetic nanoparticles termed 'MNP-CLEA-lipase'. One of the main advantages of this method is, the biocatalyst can be easily recovered by a magnetic field for recycling. In this research, dialdehydic pectin was used as the cross-linking agent, replacing glutaraldehyde, and soy protein was used as an additive, replacing bovine serum albumin (BSA). The operating conditions for the preparation of the most active MNP-CLEAlipase were optimized statistically. Dialdehydic pectin and soy protein showed optimum operating conditions at $180 \mathrm{mg} / \mathrm{mL}$ and $0.6 \%$ (w/v) respectively and with $\left(\mathrm{NH}_{4}\right)_{2} \mathrm{SO}_{4}$ at $80 \%$ saturation, giving a Residual Activity (RA) of $154 \%$. The optimum temperature for MNP-CLEA-lipase was at $40^{\circ} \mathrm{C}(127 \% \mathrm{RA})$ while the optimum $\mathrm{pH}$ was at $8(127 \% \mathrm{RA})$. It retained $20 \%$ RA after 100 days of storage. The reusability test showed that it maintained $7 \%$ RA after the 10th cycle. This research showed two advantages; first, that value-added products can be recovered from agricultural waste, and second, by alternating to low-cost food-grade cross-linkers and additives, enhanced biocatalyst can be produced which can be safely used in the beverage and food industries.
\end{abstract}

Keywords: MNP-CLEA-lipase, Hevea brasiliensis, cross-linked enzyme aggregates (CLEA), macromolecular cross-linker, glutaraldehyde, pectin, soy protein
Volume 7 Issue 5 - 2020

\author{
Nur Amalin Abd Aziz AI Safi, Faridah Yusof, \\ Azlin Suhaida Azmi \\ Department of Biotechnology Engineering, International Islamic \\ University Malaysia, Malaysia
}

\author{
Correspondence: Faridah Yusof, Department of Biotechnology \\ Engineering, Faculty of Engineering, International Islamic \\ University Malaysia, P.O. Box 10, 50728 Kuala Lumpur, Malaysia, \\ Tel 603-642। 4597, Fax 603-642I 4442, \\ Email yfaridah@iium.edu.my
}

Received: September 13,2020 | Published: October 13, 2020
Abbreviations: CLEA, cross-linked enzyme aggregates; MNP, magnetic nanoparticles; RA, residual activity; BSA, bovine serum albumin; FCCCD, face centred central composite design; RSM, response surface methodology; FESEM, field emission scanning electron microscopy

\section{Introduction}

Natural rubber (cis-1,4-polyisoprene) of Hevea brasiliensis is highly used in the latex-based industry to produce such products like tires, latex gloves, latex threads, and rubber catheters. ${ }^{1}$ As a basic raw material in rubber processing, fresh field latex undergoes many procedures during its conversion to dry rubber or high concentrated latex, whereby, the processing usually involves three methods: centrifugation, creaming, and evaporation. ${ }^{2-4}$ Some of the processes have been carried out by chemical treatment that poses a lot of negative impacts on the environment. 2 High concentrated latex is prepared by treating the natural rubber with ammonia and then centrifuged to separate the aqueous part from the concentrated rubber. This aqueous part is called skim latex which is one of the most polluting wastes in the rubber industry. ${ }^{5}$ Before being discharged into the main water system, skim latex is usually pre-treated in the effluent treatment oxidation pond. ${ }^{1}$ Converting skim latex into valuable substances would become an alternative to minimize the discharging of effluent into the main waterways, thus making latex processing more environment friendly.

Lipid acyl hydrolase, a subtype of lipase, is one of the potential proteins that can be recovered from the latex serum. ${ }^{5}$ This enzyme has been immobilized by Cross-Linked Enzyme Aggregates (CLEA) technology which is a carrier-free immobilized enzyme technique for biocatalysis. ${ }^{6,7}$ Traditionally, CLEA preparation involves protein precipitation using precipitants such as ammonium sulphate $\left[\left(\mathrm{NH}_{4}\right)_{2} \mathrm{SO}_{4}\right]$, followed by the cross-linking process by crosslinkers such as glutaraldehyde. CLEA combines purification and immobilization into a single operation to provide highly stable and recyclable catalysts with remarkable catalytic efficiency. ${ }^{8}$ However, CLEA only works well when the enzyme has enough lysine (amine residues) which links the enzyme and the cross-linker. Insufficient cross-linking might lead to enzyme leaching into the reaction media and poor stability. ${ }^{9}$ CLEA processing usually involves separation by centrifugation or filtration which would end up as clumps due to low compression resistance. This may have inhibited the internal mass transport of substrate and hence, reduce the catalytic activity. ${ }^{10}$ Magnetic cross-linked enzyme aggregates (magnetic CLEAs) is a new improvement in CLEA technology which has been proven to enhance the catalytic activity of CLEA-immobilized enzymes by increasing its cross-linking ability which leads to improved stability and catalytic activity. ${ }^{10-12}$ For the preparation of magnetic CLEAs, amino-functionalized magnetic nanoparticles (MNPs) are added into the enzyme solution for immobilization. There are two great advantages to this method. First, the functionalized MNPs add more amine residues to generate more cross-linking of the enzyme aggregates which increases the mechanical stability of CLEAs and produces non-leachable CLEAs. Second, the magnetic properties of CLEAs help in the separation of this biocatalyst from the reaction mixture using a magnetic field, whereby this process solves the clump formation problems caused by centrifugation or filtration and makes recycling the immobilized enzyme much easier. ${ }^{10,11}$ 
Cross-linking agents play important role in locking the enzyme aggregates to form the solid biocatalyst. Glutaraldehyde is the common type of cross-linker used for CLEA technology due to its low price and availability in commercial quantities.8 However, glutaraldehyde is not compatible with certain enzymes such as nitrilases which leads to low activity retention. Also, glutaraldehyde's small-sized molecule and high reactivity allows it to leach into the enzyme's active site which would lead to low activity retention. ${ }^{8,10}$ Nadar et al., ${ }^{9}$ and Gupta et al., ${ }^{13}$ discovered that macromolecular cross-linker such as dialdehydic pectin can replace glutaraldehyde in CLEA-immobilization while increasing the immobilized enzyme's activity. Pectin is not a natural cross-linker and for it to become a cross-linker, aldehydic carbonyl functional groups are introduced to the molecules by periodate oxidation. Using pectin, a food-based molecule in the preparation of biocatalyst is encouraging because it would not harm the environment as well as can be safely used in food and beverage industries.

Another compound that may be added in the preparation of CLEA, to stabilize and enhance the enzyme's activity is additives. There are three main categories of additives commonly used in enzyme immobilization, such as proteic co-feeders, organic mediums, and surfactants. Each of these additives affects the final immobilized enzyme differently, but positively enhancing their activities. Protein co-feeder is commonly added to the CLEA mix when the enzymes are known to be low in concentration. Low enzyme concentrations may result in inadequate cross-linking and this may lead to CLEA with low stability and easily leachable, thus a second protein added, such as bovine serum albumin (BSA), could improve the CLEA structure by providing additional lysine residues to react with the crosslinker.14 Additives can also prevent the leaching of cross-linkers into the enzyme's active site. ${ }^{14,15}$ As for organic medium, for example, n-heptane has been used by Guauque Torres et al., ${ }^{16}$ which resulted in higher CLEA activity. This is mainly due to the increase in CLEAs interfacial activation leading to better interaction between the enzyme and the substrate as well as with the cross-linker. ${ }^{16}$ And finally, anionic surfactant may be added to CLEAs preparation, which aims in facilitating the precipitation of enzyme into a stable conformation. ${ }^{17}$ Gupta et al. ${ }^{17}$ observed an efficient cross-linking with an increase in CLEA activity in the presence of sodium dodecyl sulfate (SDS) by two folds. Moreover, surfactants preferentially interact with some of the binding sites of an enzyme or form more powerful hydrophobic bonds than existing ones and thus changing the enzyme structure, thereby affecting the activity. ${ }^{18}$ However, in this study, we are focusing on enhancing CLEA by adding proteic co-feeder by using food grade products. Since common proteic additive such as BSA is expensive and can increase the final cost of the biocatalyst, ${ }^{19}$ Karimpil et al. ${ }^{20}$ discovered a cheaper food-grade additive, soy protein, which can replace BSA as an additive in CLEA-immobilization. Soy protein is rich in lysine residues which can facilitate cross-linking of enzymes.

In this research, dialdehydic pectin as the cross-linker and soy protein as a proteic additive are used in the production of the foodgrade biocatalyst. The preparation conditions of this biocatalyst are optimized statistically using Face Centred Central Composite Design (FCCCD) under Response Surface Methodology (RSM) with the aid Design Expert ${ }^{\circledR}$ software (Version 11). This biocatalyst could be a discovery in producing eco-friendlier and more cost-effective MNPCLEA immobilized enzymes with enhanced stability, targeting the food and beverage industries.

\section{Material and methods}

\section{Preparation of skim latex serum}

Glacial acetic acid was added to skim latex to reduce the $\mathrm{pH}$ from 10 to 5 , upon which the rubber particles coagulated. Then, the acidified sample was centrifuged at $10000 \mathrm{rpm}$ at $4^{\circ} \mathrm{C}$ for $30 \mathrm{~min}$ to separate the supernatant (skim latex serum) from the coagulated rubber (skim rubber). Solid (NH4)2SO4 was added to the pooled supernatant, up to $4 \mathrm{M}$ concentration, and left to precipitate overnight under slow stirring at $4^{\circ} \mathrm{C}$. Then, the samples were centrifuged at $5000 \mathrm{rpm}$ for 15 min and the collected precipitate was dissolved in minimal phosphate buffer saline (PBS) at $\mathrm{pH} 7.5$.

\section{Protein assay}

Protein assay was conducted according to Bio-Rad Bradford, ${ }^{21}$ by using the micro-assay method. The linear range of the assay for standard BSA is 0.1 to $1.0 \mathrm{mg} / \mathrm{mL} .800 \mu \mathrm{L}$ of each standard and sample solution was pipetted into a clean, dry test tube. Protein solutions were assayed in triplicates. $200 \mu \mathrm{L}$ of diluted dye reagent was added to each tube and vortexed. The samples were incubated at room temperature for $5 \mathrm{~min}$. The absorbance of the samples was measured at 595 $\mathrm{nm}$ using Thermo Scientific Multiskan $\mathrm{Go}^{\mathrm{TM}}$ Spectrophotometer. The protein content was calculated based on the equation from the standard curve obtained. ${ }^{5}$

\section{Lipase enzyme activity assay}

Substrate stock solution was prepared by dissolving $28 \mathrm{mg}$ of p-nitrophenyl palmitate (pNPP) in Triton 100-X (100 mL, 1\% v/v) and SDS $(1.7 \mathrm{~mL}, 1 \% \mathrm{w} / \mathrm{v})$ while stirring and heating. To start the assay reaction, $1 \mathrm{~mL}$ of pNPP stock solution was incubated with Tris$\mathrm{HCl}(1 \mathrm{~mL}, 0.1 \mathrm{M}, \mathrm{pH} 8.2)$ and $1 \mathrm{~mL}$ of the enzyme in a water bath for $30 \mathrm{~min}$ at $37^{\circ} \mathrm{C} . \mathrm{NaOH}(1 \mathrm{~mL}, 1 \mathrm{M})$ was added to stop the reaction and vortexed. The absorbance of the samples was measured at $410 \mathrm{~nm}$. One unit of lipase enzyme activity is defined as the amount of enzyme required to release $1.0 \mu \mathrm{mol}$ of $\mathrm{p}$-nitrophenol per minute under the assay conditions. ${ }^{22,23}$ Lipase activity was calculated using Eq. (1).

$$
\text { Lipase activity }\left(\frac{\text { Units }}{\mathrm{ml}}\right)=\frac{(\text { Absorbance at } 410 \mathrm{~nm}) \times \text { Total volume of assay }(\mathrm{mL})}{\text { volume of lipase }(\mathrm{mL}) \times \text { Time of assay }(\mathrm{min}) \times \text { slope }}
$$

Specific activity is calculated according to Eq. (2):

$$
\text { Specific activity }\left(\frac{U}{m g}\right)=\frac{\text { Lipase activity }(U / m l)}{\text { Total protein content }(m g / m l)}
$$

\section{Preparation of magnetic nanoparticles}

Ferric chloride $\left(\mathrm{FeCl}_{3} .6 \mathrm{H}_{2} \mathrm{O}, 1.351 \mathrm{~g}\right)$ and ferrous sulphate $\left(\mathrm{FeSO}_{4} .7 \mathrm{H}_{2} \mathrm{O}, 0.6852 \mathrm{~g}\right)$ were added to $25 \mathrm{~mL}$ deionized water. Ammonium hydroxide $\left(\mathrm{NH}_{4} \mathrm{OH}\right)$ was added to the solution until a precipitate was obtained at room temperature. To remove the residual ions, the precipitate was centrifuged and washed several times with deionized water until a $\mathrm{pH} 7$ was obtained. The precipitate was dried at $100 \mathrm{oC}$ for $3 \mathrm{~h}$ to obtain dried magnetite nanoparticles. ${ }^{12}$ The surface of the particles is coated with 3-aminopropyl triethoxysilane (APTES) by silanization reaction to obtain amino-functionalized MNPs (fMNPs). The silanization reaction involved dissolving $1 \mathrm{~mL}$ of APTES, $2 \mathrm{~g}$ of MNPs, and $0.25 \mathrm{~mL}$ of deionized water in $25 \mathrm{~mL}$ of methanol. The mixture was sonicated for $30 \mathrm{~min}$. Glycerol $(15 \mathrm{~mL})$ was added to the mixture, and the solution was incubated at $80^{\circ} \mathrm{C}$ for $6 \mathrm{~h}$ at $200 \mathrm{rpm}$. The precipitate obtained was washed with water 
and methanol for three times in each case and dried, yielding a fine powder. ${ }^{10,14,17}$ For working MNP suspension, $20 \mathrm{mg}$ of fine fMNPs was suspended in PBS.

\section{Preparation of dialdehydic pectin}

The periodate oxidation process was conducted to introduce aldehydic carbonyl functional groups to the pectin molecules. Pectin was dissolved in a volume ratio of 80:20, water: ethanol. For oxidation, sodium meta periodate $\left(\mathrm{NaIO}_{4}\right)(3 \mathrm{~mL}, 0.5 \mathrm{M})$ was added and the $\mathrm{pH}$ of the solution was adjusted to 3.5 using dilute $\mathrm{HCl}$ and sodium bicarbonate $\left(\mathrm{NaHCO}_{3}\right)$ solution. Oxidation was carried out under constant stirring for $3 \mathrm{~h}$ in the dark at $60^{\circ} \mathrm{C}$. Ethylene glycol $(3 \mathrm{~mL})$ was added to stop the oxidation. Then, the oxidized pectin was precipitated out by adding excess isopropanol and separated by vacuum filtration..$^{13,24-26}$ The precipitate was dried at $40^{\circ} \mathrm{C}$ overnight. ${ }^{24}$ Before being used as a cross-linker, dried dialdehydic pectin was dissolved in sodium acetate buffer $(0.1 \mathrm{M}, \mathrm{pH} 6.0)$ to make $0.42 \mathrm{~mol} / \mathrm{L}$ aldehyde content which is equivalent to glutaraldehyde. ${ }^{13,24-26}$

\section{Preparation of MNP-CLEA-lipase}

To prepare MNP-CLEA-lipase, $20 \mathrm{mg}$ amino-functionalized MNP was first mixed with $1 \mathrm{~mL}$ of free lipase enzyme solution. Then, varying amounts of $(\mathrm{NH} 4)_{2} \mathrm{SO}_{4}$, dialdehydic pectin, and soy protein were added to the mixture of enzyme solution to make a final volume of $4 \mathrm{~mL}$ solution. ${ }^{27}$ The solution was agitated at $200 \mathrm{rpm}$ for $17 \mathrm{~h}$ at room temperature. The immobilized enzymes were washed three times using distilled water and separated from the reaction mixture using a magnet. The RA of MNP-CLEA-lipase was obtained by conducting the lipase enzyme activity assay..$^{10}$ The RA of CLEAlipase was determined using Eq. (3).

$$
\mathrm{RA}(\%)=\frac{\text { total activity of } M N P-C L E A-\text { lipase }}{\text { total activity of free lipase for CLEA preparation }} \times 100 \%
$$

\section{Optimization of condition parameters for preparing MNP-CLEA-lipase}

The optimum condition parameters for preparing MNP-CLEAlipase were experimentally determined using FCCCD under RSM with the aid Design Expert ${ }^{\circledR}$ software (Version 11). The software helps to determine the interactions between each parameter used in the experiment. The parameters involved were concentrations of dialdehydic pectin as cross-linker, $\left(\mathrm{NH}_{4}\right)_{2} \mathrm{SO}_{4}$, and soy protein as additive. A total of 20 experiment runs were prescribed including six replications at the center point. Each run was conducted in triplicates and an average was reported. Statistical analysis was done using ANOVA to evaluate the degree of accuracy of the derived model equation.

\section{Validation experiments}

Three validation experiments were carried out to check on the authenticity of the model experiment. The reliability of the model experiment was given by the percentage error of the predicted and the actual value of RA of MNP-CLEA-lipase, calculated using Eq. (4).

$$
\operatorname{Error}(\%)=\left|\frac{\text { Predicted value }- \text { Actual value }}{\text { Predicted value }}\right| \times 100 \%
$$

\section{Determination of optimum temperature and $\mathrm{pH}$}

To determine the optimum temperature for MNP-CLEA-lipase, the lipase enzyme activity assay was conducted at different incubation temperatures $\left(25\right.$ to $\left.60^{\circ} \mathrm{C}\right)$. To measure the optimum $\mathrm{pH}$, lipase enzyme activity assay was conducted as usual but at optimum temperature and at various $\mathrm{pH}$ ( 5 to 10$){ }^{27,28}$ The optimum temperature and $\mathrm{pH}$ were determined according to the highest RA obtained.

\section{Thermal and pH stabilities}

For the thermal stability test, MNP-CLEA-lipase was incubated in a substrate-free buffer at optimum $\mathrm{pH}$ for $30 \mathrm{~min}$ at temperatures between $25^{\circ} \mathrm{C}$ to $60^{\circ} \mathrm{C}$. After incubation, the samples were brought back to room temperature and the substrate was added. Then, the samples were incubated again at the temperature for $30 \mathrm{~min}$. As for the $\mathrm{pH}$ stability test, MNP-CLEA-lipase was incubated in a substrate-free buffer at various $\mathrm{pH}$ ranging from 5 to 10 at the optimum temperature for $30 \mathrm{~min}$. After $30 \mathrm{~min}$, the substrate was added, and the samples were incubated at optimum temperature for another 30 min.6

\section{Storage stability}

Storage stability was determined by storing MNP-CLEA-lipase in sodium acetate $\left(\mathrm{NaCH}_{3} \mathrm{CO}_{2}\right)$ buffer $(0.1 \mathrm{M}, \mathrm{pH} 5)$ without substrate at $4{ }^{\circ} \mathrm{C}$. Lipase enzyme activity assay was carried out every five days for 100 days. ${ }^{13}$ The RA of MNP-CLEA-lipase for Day 1 was set as $100 \%$.

\section{Reusability test}

The enzyme reusability test for MNP-CLEA-lipase was done by recycling MNP-CLEA-lipase for 10 consecutive cycles. The assayed MNP-CLEA-lipase (first cycle) was washed and stored in $3 \mathrm{~mL}$ of water at $4^{\circ} \mathrm{C}$ for $24 \mathrm{~h}$, whereby the assay was repeated nine more times. The RA was calculated by taking the enzyme activity of the first cycle as $100 \%{ }^{6}$

\section{Morphology analysis by FESEM}

Field Emission Scanning Electron Microscopy (FESEM) analyses were conducted to analyze the structure of MNP-CLEA-lipase. The appearance of the sample could either be spherical (Type 1) or lessstructured (Type 2). ${ }^{29}$ MNP-CLEA-lipase and non-functionalized MNP samples were sent to Crest Nanosolutions (M) Sdn. Bhd., Puchong, Selangor, for FESEM analysis. The FESEM was operated at $10 \mathrm{kV}$ using FEI Quanta FEG. The samples were dried and placed on an aluminium stab, then coated with gold particles before being scanned under vacuum.

\section{Results}

\section{Optimization of preparation condition for MNP-CLEA-lipase}

Results (not shown) obtained from the One-At-a-Time (OFAT) experimental method were used to design the FCCCD experimental runs. OFAT results showed that the best preparation conditions were obtained by using three parameters, namely, the concentrations of dialdehydic pectin, soy protein, and (NH4) $\mathrm{SO}_{4}$ at $180 \mathrm{mg} / \mathrm{mL}, 0.6 \%$ $(\mathrm{w} / \mathrm{v})$ and $80 \%$ saturation, respectively. The optimum preparation conditions and the interaction between these three parameters were studied using FCCCD under RSM with the aid of Design Expert ${ }^{\circledR}$ (Version 11) software. In the FCCCD method, the concentrations for dialdehydicpectin were varied at 170,180 and $190 \mathrm{mg} / \mathrm{mL}$, for soy protein was $0.5,0.6$ and $0.7 \%(\mathrm{w} / \mathrm{v})$ and for $(\mathrm{NH} 4)_{2} \mathrm{SO}_{4}$ was 70,80 and $90 \%$ saturation. RA (\%) of lipase enzyme activities were recorded as the responses.

The details of the software suggested 20 experimental runs (inclusive of six replications at the center point) are shown in Table 1. The highest RA was obtained at $180 \mathrm{mg} / \mathrm{mL}$ of dialdehydic pectin, 
$0.6 \%(\mathrm{w} / \mathrm{v})$ of soy protein, and $80 \%$ saturation of $(\mathrm{NH} 4)_{2} \mathrm{SO}_{4}$ with a RA of $154 \%$. Results showed that concentrations of dialdehydic pectin, soy protein, and $\left(\mathrm{NH}_{4}\right)_{2} \mathrm{SO}_{4}$ affected the lipase enzyme's $\mathrm{RA}$ and were optimum at the center points. The analysis of variance (ANOVA) data in Table 2 showed that the model F-value of 50.48 implies that the model is significant. There is only a $0.01 \%$ chance that an F-value this large could occur due to noise. A P-value less than
0.05 indicates that the model terms are significant while values greater than 0.1 indicate that the model terms are not significant. ${ }^{27,30}$ The model terms are presented in coded factors A, B, A2, B2, and C2. The regression model equation for this experimental design is as Eq. (5) which signifies the relationship between the response (RA) and the variables (concentrations of pectin, $\left(\mathrm{NH}_{4}\right)_{2} \mathrm{SO}_{4}$, and soy protein). The regression equation obtained for the model is as follows:

$$
\text { Residual activity }=139.35+16.90 A-8.20 B-5.40 C+0.00 A B-1.00 A C+2.75 B C-74.86 A^{2}-51.36 B^{2}+17.64 C^{2}
$$

Table I Design of experiment of FCCCD under RSM by design expert ${ }^{\circledR}$ (Version II)

\begin{tabular}{|c|c|c|c|c|}
\hline Run & Factor I & Factor 2 & Factor 3 & Response \\
\hline & $\begin{array}{l}\text { A: Concentration of } \\
\text { pectin }\end{array}$ & $\begin{array}{l}\text { B: Concentration of } \\
\text { (NH4)2SO4 }\end{array}$ & $\begin{array}{l}\text { C: Concentration of soy } \\
\text { protein }\end{array}$ & $\begin{array}{l}\text { Residual } \\
\text { Activity }\end{array}$ \\
\hline & $(\mathrm{mg} / \mathrm{ml})$ & (\% Saturation) & $(\% w / v)$ & (\%) \\
\hline I & $180(0)$ & $80(0)$ & $0.6(0)$ & 137 \\
\hline 2 & $180(0)$ & $70(-1)$ & $0.6(0)$ & 88 \\
\hline 3 & $190(+1)$ & $80(0)$ & $0.6(0)$ & 75 \\
\hline 4 & $180(0)$ & $80(0)$ & $0.6(0)$ & 156 \\
\hline 5 & $190(+1)$ & $70(-1)$ & $0.5(-1)$ & 65 \\
\hline 6 & $180(0)$ & $80(0)$ & $0.6(0)$ & 142 \\
\hline 7 & $180(0)$ & $80(0)$ & $0.6(0)$ & 154 \\
\hline 8 & $180(0)$ & $80(0)$ & $0.6(0)$ & 145 \\
\hline 9 & $190(+1)$ & $70(-1)$ & $0.7(+1)$ & 49 \\
\hline 10 & $190(+I)$ & $90(+1)$ & $0.5(-1)$ & 46 \\
\hline II & $170(-1)$ & $70(-1)$ & $0.7(+1)$ & 17 \\
\hline 12 & $180(0)$ & $80(0)$ & $0.6(0)$ & 142 \\
\hline 13 & $170(-1)$ & $70(-1)$ & $0.5(-1)$ & 33 \\
\hline 14 & $180(0)$ & $80(0)$ & $0.5(-1)$ & 153 \\
\hline 15 & $180(0)$ & $90(+1)$ & $0.6(0)$ & 68 \\
\hline 16 & $170(-1)$ & $90(+1)$ & $0.7(+1)$ & 9 \\
\hline 17 & $180(0)$ & $80(0)$ & $0.7(+1)$ & $|4|$ \\
\hline 18 & $170(-1)$ & $80(0)$ & $0.6(0)$ & 34 \\
\hline 19 & $170(-1)$ & $90(+1)$ & $0.5(-1)$ & 10 \\
\hline 20 & $190(+I)$ & $90(+1)$ & $0.7(+1)$ & 37 \\
\hline
\end{tabular}

Table 2 ANOVA for experimental results of FCCCD by design expert ${ }^{\circledR}$ (Version II)

\begin{tabular}{|c|c|c|c|c|c|c|}
\hline Source & $\begin{array}{l}\text { Sum of } \\
\text { Squares }\end{array}$ & df & $\begin{array}{l}\text { Mean } \\
\text { Square }\end{array}$ & F-value & p-value & \\
\hline Model & 56372.21 & 9 & 6263.58 & 50.48 & $<0.0001$ & significant \\
\hline A-Concentration of pectin & 2856.1 & 1 & 2856.1 & 23.02 & 0.0007 & \\
\hline B-Concentration of ammonium sulphate & 672.4 & 1 & 672.4 & 5.42 & 0.0422 & \\
\hline C-Concentration of soy protein & 291.6 & 1 & 291.6 & 2.35 & 0.1563 & \\
\hline$A B$ & $7.28 \mathrm{E}-12$ & I & $7.28 \mathrm{E}-12$ & $5.86 \mathrm{E}-14$ & I & \\
\hline AC & 8 & 1 & 8 & 0.0645 & 0.8047 & \\
\hline BC & 60.5 & 1 & 60.5 & 0.4876 & 0.5009 & \\
\hline$A^{2}$ & $154 \mid 2.55$ & I & $154 \mid 2.55$ & 124.22 & $<0.0001$ & \\
\hline$B^{2}$ & 7255.11 & I & 7255.11 & 58.47 & $<0.0001$ & \\
\hline
\end{tabular}


Table continue

\begin{tabular}{|c|c|c|c|c|c|c|}
\hline Source & $\begin{array}{l}\text { Sum of } \\
\text { Squares }\end{array}$ & df & $\begin{array}{l}\text { Mean } \\
\text { Square }\end{array}$ & F-value & p-value & \\
\hline$C^{2}$ & 855.36 & I & 855.36 & 6.89 & 0.0254 & \\
\hline Residual & 1240.74 & 10 & 124.07 & & & \\
\hline Lack of Fit & 962.74 & 5 & 192.55 & 3.46 & 0.0995 & not significant \\
\hline Pure Error & 278 & 5 & 55.6 & & & \\
\hline Cor Total & 57612.95 & 19 & & & & \\
\hline
\end{tabular}

\section{Optimum temperature and $\mathrm{pH}$}

The optimum temperature and $\mathrm{pH}$ of MNP-CLEA-lipase was determined by incubating the enzyme at different temperatures and $\mathrm{pH}$ conditions. The optimum temperature obtained for MNP-CLEAlipase is $40^{\circ} \mathrm{C}$ with $127 \%$ RA as shown in Figure 1. MNP-CLEAlipase exhibited high RA even at high temperature, showing a RA above $90 \%$ at $60^{\circ} \mathrm{C}$. As for the $\mathrm{pH}$, the highest RA of MNP-CLEAlipase was achieved at $\mathrm{pH} 8$ with RA of $127 \%$ as shown in Figure 2. It is observed that MNP-CLEA-lipase maintains a high RA even at extreme $\mathrm{pH}$ conditions but is optimum at $\mathrm{pH} 8$.

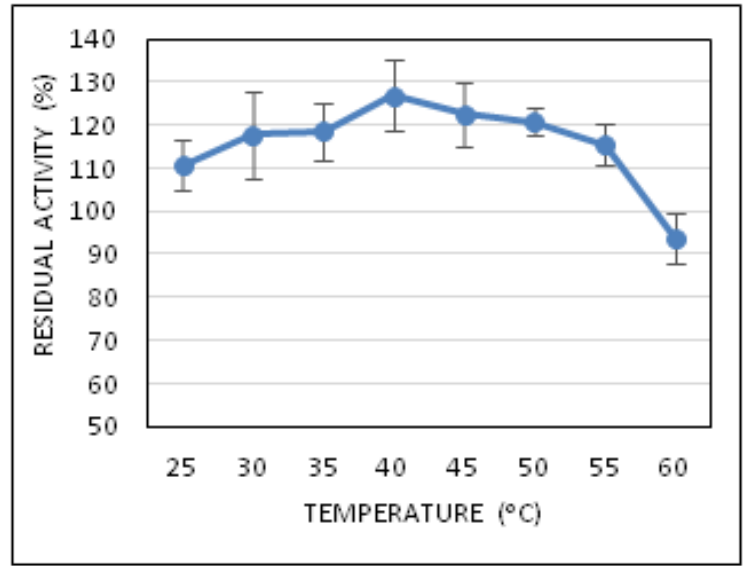

Figure I Optimum Temperature for MNP-CLEA-Lipase.

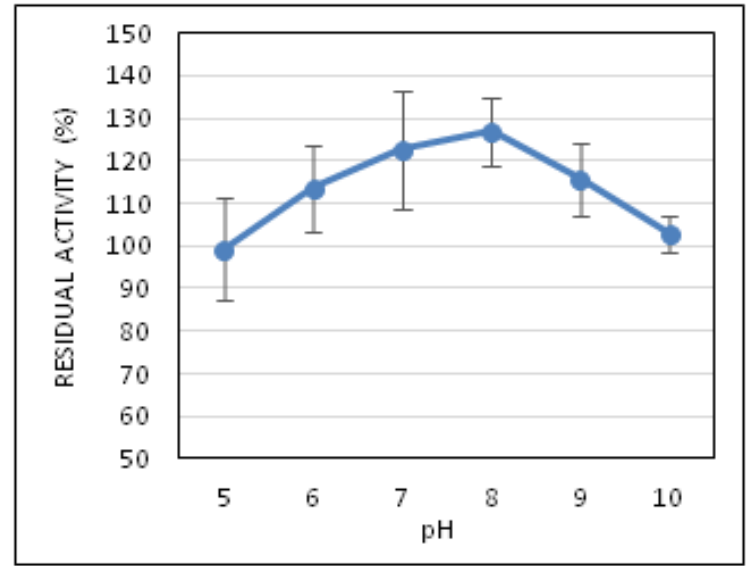

Figure 2 Optimum pH for MNP-CLEA-Lipase.

\section{Thermal and $\mathrm{pH}$ stability}

The thermal stability of MNP-CLEA-lipase was conducted by incubating the enzyme without substrate at different temperatures at the optimum $\mathrm{pH}$ before running the standard lipase enzyme activity assay. On the other hand, the $\mathrm{pH}$ stability test was carried out by incubating the enzyme without substrate at different $\mathrm{pH}$ at the optimum temperature, before running the standard lipase enzyme activity assay. According to Figure 3, MNP-CLEA-lipase maintained its stability even at high temperature, whereby at $60^{\circ} \mathrm{C}$ the biocatalyst was shown to still retaining $98 \%$ RA. Figure 4 shows that MNPCLEA-lipase has high stability towards extremes $\mathrm{pH}$ conditions, retaining a $\mathrm{RA}$ up to $99 \%$ at $\mathrm{pH} 5$ and $107 \%$ at $\mathrm{pH} 10$.

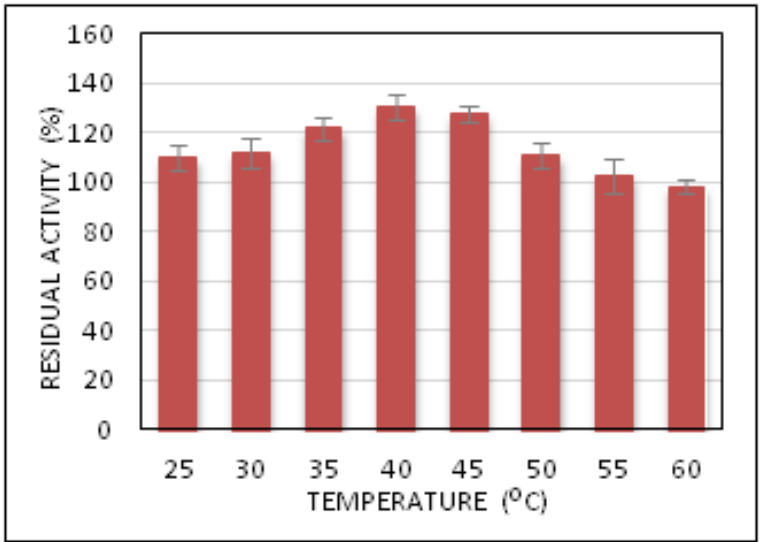

Figure 3 Thermal Stability of MNP-CLEA-Lipase Tested from $25^{\circ}$ to $60^{\circ} \mathrm{C}$.

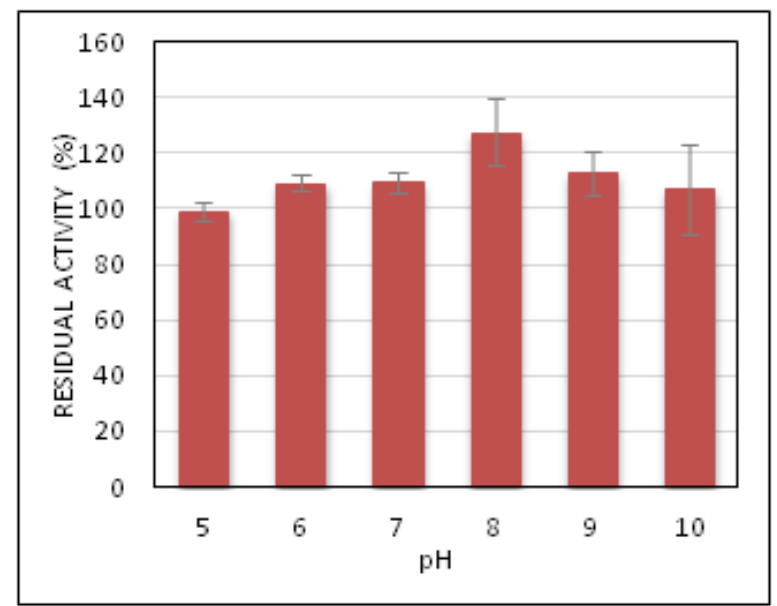

Figure $4 \mathrm{pH}$ Stability of MNP-CLEA-lipase Tested from $\mathrm{pH} 5$ to 10.

\section{Storage stability}

Storage stability was carried out to study MNP-CLEA-lipase's activity up to 100 days of storage. A batch of MNP-CLEA-lipase samples was stored in sodium acetate buffer $(0.1 \mathrm{M}, \mathrm{pH} 5)$ without substrate at $4^{\circ} \mathrm{C}$. The stored enzymes were assayed every five days to obtain their RA. The RA of MNP-CLEA-lipase for Day 1 was taken as $100 \%$. From Figure 5, the RA of MNP-CLEA-lipase was observed to decrease gradually as it retained a RA of above $50 \%$ of its initial activity until day 40 , and it continued to decrease to $20 \%$ after reaching the 100th day. ${ }^{31-35}$ 


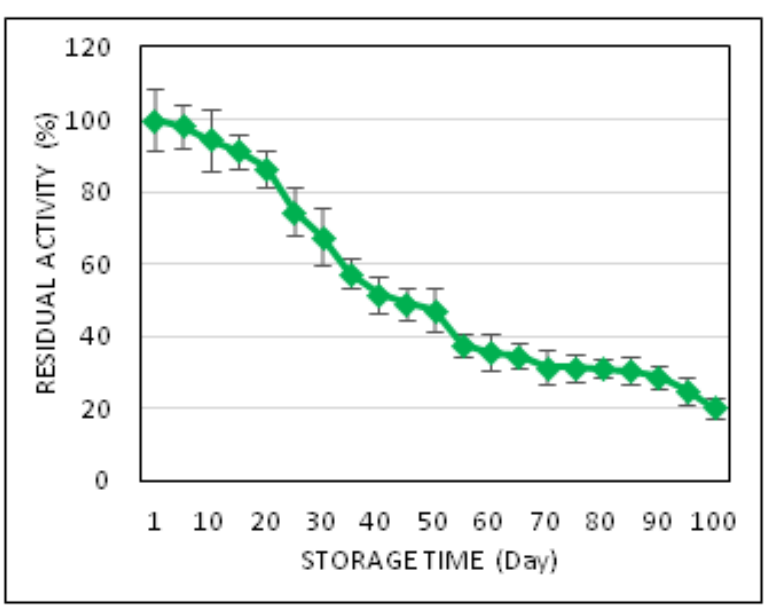

Figure 5 Storage Stability of MNP-CLEA-lipase Tested for 100 Days.

\section{Reusability}

The reusability test is an important factor for the immobilized enzymes to be used in industrial applications to ensure its costeffectiveness. ${ }^{10,26,35}$ The reusability test of MNP-CLEA-lipase was carried out for 10 cycles and the first cycle was set at 100\% RA. The results in Figure 6 showed that the RA of MNP-CLEA-lipase decreased continuously in each cycle and only retained $7 \%$ of RA on the 10th cycle. However, it is very laudable to have the MNP-CLEAlipase achieving a RA of $44 \%$ at its 4 th cycle of usage.

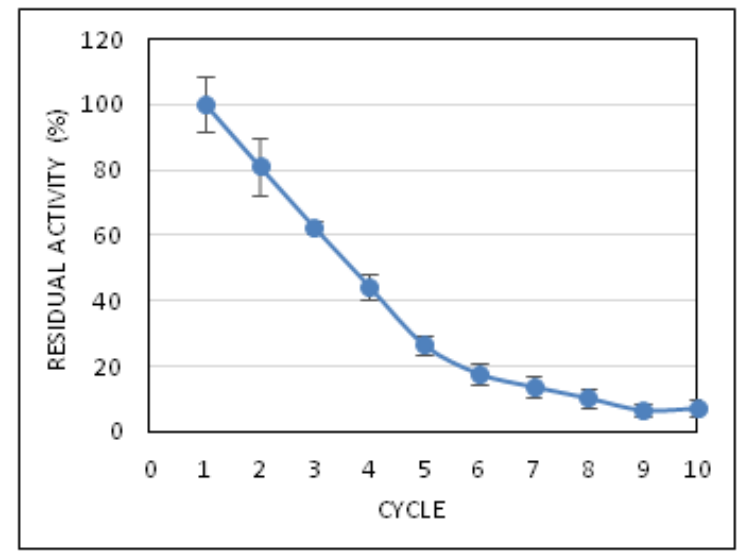

Figure 6 Reusability of MNP-CLEA-Lipase after 10 Cycles of Usages.

\section{Scanning electron microscopy by FESEM and EDX}

Figures 7 showed the observed FESEM images whereby Figure 7(a) illustrates the images of functionalized MNPs before it was added to CLEA-immobilization. The MNPs appeared to be spherical in shape and loosely aggregated. The diameter of the MNPs was estimated at about 20-60 nm. Figure 7(b) shows the image of CLEA-lipase with glutaraldehyde, without the addition of MNPs. The structure of CLEAlipase was less structured with the formation of clumps. On the other hand, MNP-CLEA-lipase with pectin and soy protein (Figure 7(c)) appeared to be less structured but with lesser clumping. The addition of MNPs seems to give an improved modification to the structure of the immobilized lipase due to more sufficient cross-linking. Lastly, Figure 7(d) shows the structure of MNP-CLEA-lipase with glutaraldehyde. It appeared to also be less structured with the formation of clumps on the surface. In EDX, the x-rays are produced by inelastic scattering of primary beam electrons with bound inner shell electrons during their penetration into the matter. The $\mathrm{x}$-rays enable the determination of the elemental compositions of a sample.38 The EDX results (not shown) showed that MNP-CLEA-lipase containing the highest number of oxygen and CLEA-lipase containing the highest number of carbon. MNP-CLEA-lipase was shown to have iron which indicates that the immobilized enzyme was successfully bonded with MNPs. The presence of some foreign elements such as boron indicates some slight contamination in the samples.

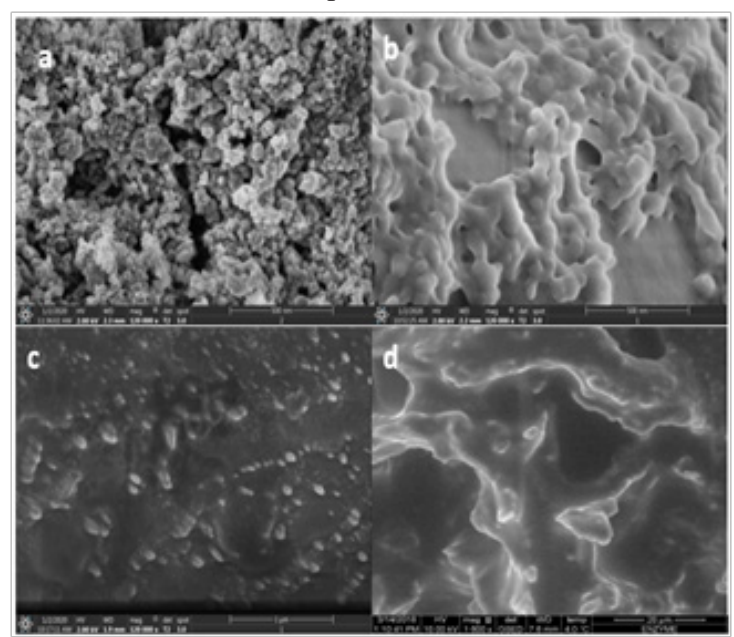

Figures 7 FESEM Images of a) Functionalized MNPs (I20000x), b) CLEALipase $(120000 \times)$, c) MNP-CLEA-Lipase with Dialdehydic Pectin as crosslinker and Soy Protein as Additive (I20000x), d) MNP-CLEA-Lipase with Glutaraldehyde as cross-linker (1600x).

\section{Discussion}

According to the ANOVA results, the concentrations of dialdehydic pectin and $\left(\mathrm{NH}_{4}\right)_{2} \mathrm{SO}_{4}$ are significant model terms as their $\mathrm{p}$-value is less than 0.05 . on the other hand, the concentration of soy protein is not a significant model term with as p-value of greater than 0.1 . This inferred that the concentrations of soy protein did not have much influence on the RA compared to concentrations of dialdehydic pectin and $\left(\mathrm{NH}_{4}\right)_{2} \mathrm{SO}_{4}$. This might be due to the smaller range used for soy protein which is $0.5,0.6$ and $0.7 \%(\mathrm{w} / \mathrm{v})$. The lack of fit value of 3.46 implies there is a $9.95 \%$ chance that a lack of fit F-value this large could occur due to noise.27,30 The model is shown to be significant with a Coefficient of Determination (R2) value of 0.9785 . The predicted R2 of 0.9188 is in reasonable agreement with the adjusted R2 of 0.9591 since the difference is less than 0.2 . Adequate precision that measures the signal to noise ratio is 20.108 which indicates an adequate signal. ${ }^{22,30,31}$ The regression equation [Eq. (5)] is represented by a three dimensional surface plot (Figure 8) which indicates the interaction between concentrations of dialdehydic pectin and $\left(\mathrm{NH}_{4}\right)_{2} \mathrm{SO}_{4}$. The concentration of soy protein was fixed at $0.6 \%(\mathrm{w} / \mathrm{v})$. A dome or maximum shape of the surface plot indicates that the interactions between the variables are significant. $22,27,31$ The results for the validation experiment is shown in Table 3. The model's predicted RA value appeared to be slightly lower than the actual RA obtained for the three runs which might be influenced by the experimental conditions. This means that the calculated results were in the zone within the border of the technological space that FCCCD considered. ${ }^{22,30,31}$ The average percentage error for the actual and predicted RA of MNP-CLEA-lipase is low of $5.01 \%$, which indicates that the model experiment is deemed to be accurate and reliable to predict the activity of MNP-CLEA-lipase. 


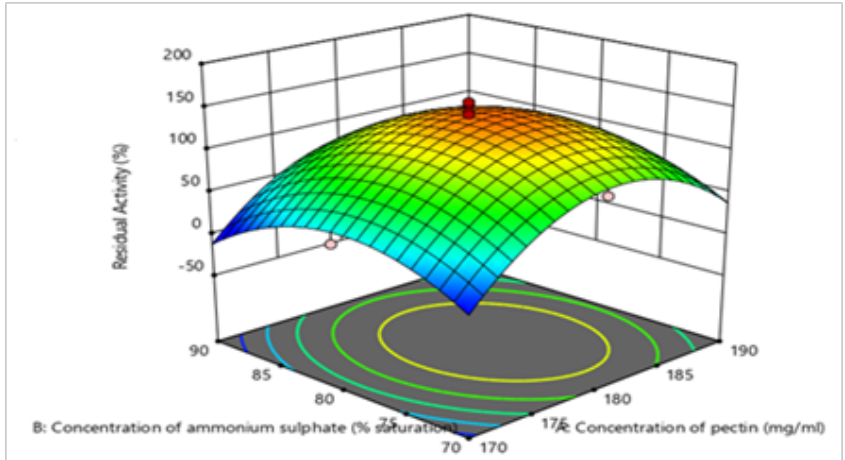

Figure 8 A Three-Dimensional Surface Plot for the Interaction of Concentration of Pectin and Concentration of $\left(\mathrm{NH}_{4}\right)_{2} \mathrm{SO}_{4}$ by RSM using

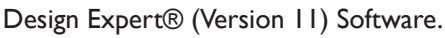

Table 3 Percentage error for model experiment validation

\begin{tabular}{lllllll}
\hline Run & A & B & C & $\begin{array}{l}\text { Actual } \\
\text { Residual } \\
\text { Activity }\end{array}$ & $\begin{array}{l}\text { Predicted } \\
\text { Residual } \\
\text { Activity }\end{array}$ & Error (\%) \\
\hline & $(\mathrm{mg} / \mathrm{ml})$ & $(\% \mathrm{SAT})$ & $(\% \mathrm{~W} / \mathrm{V})$ & $(\%)$ & $(\%)$ & \\
\hline $\mathrm{I}$ & 184.848 & 85.609 & 0.6 & 66.2 & 62.627 & 5.86 \\
2 & 182.379 & 72.579 & 0.6 & 122.207 & 116.93 & 4.51 \\
3 & 184.793 & 77.952 & 0.6 & 135.825 & 129.772 & 4.66 \\
& & & & & $\begin{array}{l}\text { Average } \\
\text { error }\end{array}$ & 5.01 \\
\hline
\end{tabular}

Optimum temperature experiments showed that MNP-CLEAlipase can achieve a maximal activity at $40^{\circ} \mathrm{C}(127 \%$ RA), and still showed a high RA of above $90 \%$ at $60^{\circ} \mathrm{C}$ (Figure 1). Talekar et al., ${ }^{10}$ $\&$ Nadar et al., ${ }^{26}$ obtained the highest RA of MNP-CLEA- $\alpha$-amylase and MNP-CLEA-glucoamylase, respectively, at $60^{\circ} \mathrm{C}$ with residual activities above $90 \%$. In a research carried out by Safi and Yusof32, MNP-CLEA-lipase of skim latex with glutaraldehyde, achieved an optimum temperature of $35^{\circ} \mathrm{C}$ with $85.89 \%$ RA. Thus, MNP-CLEAlipase with pectin showed more significantly higher RA at optimum temperature. This shows that MNP-CLEA-lipase can work at high temperatures, inferring the significant presence of covalent bonds between the lipase and the dialdehydic pectin during immobilization which decreases the conformational flexibility of lipase and protects it from distortion or damage at high temperature. ${ }^{10,26}$

MNP-CLEA-lipase showed that it achieved 127\% RA at its optimum $\mathrm{pH}$ at 8 . The results in Figure 2 showed that MNP immobilized lipase has higher activity when dialdehydic pectin and soy protein is added, and the activity is increased even higher than the control (free enzyme). Talekar et al., ${ }^{10}$ and Nadar et al. ${ }^{26}$ reported an optimum $\mathrm{pH}$ of 6 for their work on MNP-CLEA- $\alpha$-amylase and MNP-CLEA-glucoamylase, respectively. Safi \& Yusof $^{32}$ reported an optimum $\mathrm{pH} 8$ for MNP-CLEA-lipase from skim latex of Hevea brasiliensis, with glutaraldehyde but no additive, however with lower RA (69.92\%). The difference in optimum $\mathrm{pH}$ of MNP-CLEA-lipase might be caused by the alteration of acidic and basic amino acid side chain ionization in the microenvironment around the enzyme's active site. This is also caused by the new interactions formed between basic residues of lipase and pectin during cross-linking. ${ }^{10,26}$ The higher RA of MNP-CLEA-lipase with pectin compared to with glutaraldehyde might be influenced by pectin's bigger molecule size which prevents mass transfer limitations and leaching into the enzyme's active site. ${ }^{9,13}$
As for the thermal stability, results in Figure 3 show that MNPCLEA-lipase retained $98 \% \mathrm{RA}$ at $60 \mathrm{oC}$ which is higher than MNPCLEA-lipase with glutaraldehyde, reported by Safi \& Yusof ${ }^{32}(70 \%$ RA at $60^{\circ} \mathrm{C}$ ). Talekar et al. ${ }^{10}$ observed that MNP-CLEA- $\alpha$-amylase maintained RA of above $85 \%$ at 60 to $70^{\circ} \mathrm{C}$. The enhanced stability of MNP-CLEA-lipase at high- temperature conditions might be due to enough numbers of covalent cross-linking between lipase enzyme and MNPs as these covalent bonds provide an effective conformational stabilization. ${ }^{10}$ Figure 4 shows that MNP-CLEA-lipase has high stability at slightly extreme pHs, retaining up to $99 \%$ at $\mathrm{pH} 5$ and $107 \%$ at $\mathrm{pH} 10$. This indicates that MNP-CLEA-lipase is very stable in acidic and alkaline $\mathrm{pH}$ conditions. This is actually more stable to extreme $\mathrm{pH}$ 's than MNP-CLEA-lipase (with glutaraldehyde) reported by Safi and Yusof, whereby it only retained less than $60 \%$ RA at $\mathrm{pH} 10$ and less than $70 \%$ at $\mathrm{pH} 5 .^{32}$ The resistance to $\mathrm{pH}$ changes of MNP-CLEA-lipase might be caused by the efficient covalent cross-linking of enzyme aggregates with MNPs which increased the flexibility of MNP-CLEA-lipase upon extreme ionization. ${ }^{27,33}$ Having the MNP-CLEA-lipase retaining 50\% and $20 \%$ after 40 and 100 days, respectively, showed that MNP-CLEA-lipase is significantly stable after a long period of storage (Figure 5). The decrease in RA might be caused by the denaturation of lipase after some period. However, the RA decreased gradually which might be because of minimal distortion effects caused by the buffer solution on the active sites of MNP-CLEA-lipase. ${ }^{9}$ These results are in good agreement with other work such as Talekar who reported that their MNP-CLEA- $\alpha$-amylase retained $80 \%$ of initial activity after 18 days of storage ${ }^{10}$ and Kim et al. ${ }^{34}$ who reported that their MNP-CLEA-lipase retained $82 \%$ RA after 30 days of storage. ${ }^{34}$ The results implied that magnetic CLEAs are mechanically stable after a long period of storage due to effective cross-linking which prevents leakage of the enzyme into the aqueous buffer and dissociation from aggregates..$^{10,34}$

Recyclability is another important characteristic of a good biocatalyst. The results in Figure 6 showed the activity of MNPCLEA-lipase declined to $7 \%$ after the 10th usages and this may be caused by loss of enzymes during washing and inactivation of enzymes.10,26,35 Other works showed that recyclability of MNP immobilized enzymes, such as Safi and Yusof's work ${ }^{32}$ on MNPCLEA-lipase with glutaraldehyde, which retained up to $56.46 \%$ of RA on the 6th cycle, Talekar work which achieved $25 \%$ of RA on the 6th cycle for MNP-CLEA- $\alpha$-amylase and Talekar et al., ${ }^{36}$ work which obtained high retention of $85 \%$ RA for MNP-CLEAglucoamylase after the 10th cycle. The difference in retention of RA for each immobilized enzyme might be influenced by the stability of the enzyme or the cross-linking efficiency of the enzymes.

Field emission scanning electron microscopy (FESEM) is a technique to obtaining structural information on materials at nanometer-scale resolution. ${ }^{37}$ Energy-dispersive X-ray spectroscopy (EDX) determines the elemental composition of a specimen. FESEM and EDX are important aids in the determination of the relationship among catalyst particles (cluster) sizes, dispersion onto support, morphology, and the influence of promoters.38 FESEM provides imaging of features with high resolution and high contrast in the nanometer scale. Figures 7 show the FESEM images for (a) functionalized MNPs, (b) CLEA-lipase, (c) MNP-CLEA-lipase cross-linked with pectin and added soy protein, and (d) MNP-CLEAlipase cross-linked with glutaraldehyde. The results showed that MNP-CLEA-lipase with pectin and soy protein appeared to be less structured but with lesser clumping. The addition of MNPs seems to give an improved modification to the structure of the immobilized 
lipase due to more sufficient cross-linking. The formation of clumps on the surface of the CLEAs should be avoided to ensure better mass transfer. From the FESEM images obtained, it can be said that dialdehydic pectin and soy protein additive works as a better crosslinker and additive for MNP-CLEA-lipase as the result showed improved structure which translates to lesser mass transfer resistance.

According to Schoevaart et al., ${ }^{29}$ CLEAs are categorized as Type 1 (spherical shape) and Type 2 (less-structured shape). Nonsupported CLEAs can also form large clusters which may cause mass transfer limitations.29 Less structured (Type 2) particles indicate that the structure of the CLEAs was less compact compared to Type 1 structures which are spherical shaped. This is vital for ease of accessibility of larger substrates, such as p-nitrophenyl palmitate with 16 carbon, to the enzymes active site 32 . The morphology and particle size of CLEAs are also influenced by other parameters such as the concentration of enzymes, type of precipitants, cross-linkers, and additives..$^{39}$ According to Sheldon39 the particle sizes of CLEAs also affect filterability, especially for non-supported CLEAs. The RA of CLEAs are also influenced by the particle size and the rate of addition of the cross-linker and cross-linking time. ${ }^{39}$

\section{Conclusion}

Nowadays, more attempts should be made to turn any waste into value-added products which will lead to a zero-discharge scenario in many industries. In this case, utilizing skim latex waste for the discovery of biocatalyst can help to reduce the waste management problems faced by the rubber manufacturing industry and will eventually bring benefits towards the industry and the environment. Lipase is chosen as it is a very versatile enzyme that can be used in many industrial applications. The study on MNP-CLEA immobilized enzymes has increased in recent years and is still expanding as it is a very efficient enzyme immobilization method. However, to be able to be utilized in food-based industries and for environmental purposes, green, low-cost and non-toxic materials should be sought for the immobilization technique. Fortunately, low-cost food-grade cross-linkers and additives are proven to be better alternatives that can counter the problems faced by using traditional cross-linker such as glutaraldehyde and costly additives such as BSA while enhancing the enzyme's biocatalytic activity. Since they are food grade alternatives, the newly produced biocatalyst can be safely used in the food and beverage industries.

\section{Acknowledgments}

The authors would like to thank the Department of Biotechnology Engineering, Faculty of Engineering, International Islamic University of Malaysia for providing the supports to carry out the research.

\section{Conflicts of interest}

The authors declare there is no conflict of interest.

\section{Funding}

None.

\section{References}

1. Mohammadi M, Man HC, Hassan A, et al. Treatment of wastewater from rubber industry in Malaysia. African J Biotechnol. 2010;9(38):62336243.

2. Nguyen HN, Luong TT. Situation of wastewater treatment of natural rubber latex processing in the Southeastern region, Vietnam. $J$ Vietnamese Environ. 2012;2(2):58-64.
3. Ochigbo SS, Lafia-Araga RA, Suleiman MAT. Comparison of two creaming methods for preparation of natural rubber latex concentrates from field latex. African J Agric Res. 2011;6(12):2916-19.

4. Veerasamy D, Ismail AF. Rehabilitation of fouled membrane from natural rubber skim latex concentration through membrane autopsy and ultrasonication enhanced membrane cleaning procedure. Desalination. 2012;286:235-241.

5. Mohamed N, Yusof F. Experimental design and statistical analysis of protein buffer to purify hydrolases from the skim latex of Hevea brasiliensis. Adv Environ Biol. 2014;8(3):672-679.

6. Khanahmadi S, Yusof F, Chyuan Ong H, et al. Cocoa pod husk: A new source of CLEA-lipase for preparation of low-cost biodiesel: An optimized process. J Biotechnol. 2016;231:95-105.

7. Yusof F, Khanahmadi S. Carrier-Free Enzyme Immobilization by CrossLinked Enzyme Aggregates (CLEA) Technology. Multifaceted Protoc Biotechnol. 2018;93-107.

8. Sheldon RA. Cross-linked enzyme aggregates (CLEA $\AA s)$ : stable and recyclable biocatalysts. Biochem Soc Trans. 2007;35(6):1583-1587.

9. Nadar SS, Muley AB, Ladole MR, J et al. Macromolecular crosslinked enzyme aggregates (M-CLEAs) of $\alpha$-amylase. Biol Macromol. 2015;84:69-78.

10. Talekar S, Ghodake V, Ghotage T, et al. Novel magnetic cross-linked enzyme aggregates (magnetic CLEAs) of alpha amylase. Bioresour Technol. 2012;123:542-547.

11. Gupta K, Jana AK, Kumar S, et al. Immobilization of amyloglucosidase from SSF of Aspergillus niger by crosslinked enzyme aggregate onto magnetic nanoparticles using minimum amount of carrier and characterizations. J Mol Catal B Enzym. 2013;98:30-36.

12. Reza RT, Pérez CAM, González CAR, et al. Effect of the polymeric coating over $\mathrm{Fe}_{3} \mathrm{O}_{4}$ particles used for magnetic separation. Cent Eur $J$ Chem. 2010;8(5):1041-1046.

13. Gupta B, Tummalapalli M, Deopura BL, et.al. Functionalization of pectin by periodate oxidation. Carbohydr Polym. 2013;98(1):1160 1165 .

14. Roess1 U, Nahálka J, Nidetzky B. Carrier-free immobilized enzymes for biocatalysis. Biotechnol Lett. 2010;32(3):341-50.

15. Torres-Salas P, Del Monte-Martinez A, Cutiño-Avila B, et al Immobilized biocatalysts: Novel approaches and tools for binding enzymes to supports. Adv Mater. 2011;23(44):5275-5282.

16. Guauque Torres MP, Foresti ML, Ferreira ML. Effect of different parameters on the hydrolytic activity of cross-linked enzyme aggregates (CLEAs) of lipase from Thermomyces lanuginosa. Biochem Eng J. 2013;72:18-23.

17. Gupta P, Dutt K, Misra S, et.al. Characterization of cross-linked immobilized lipase from thermophilic mould Thermomyces lanuginosa using glutaraldehyde. Bioresour Technol. 2009;100(18):4074-4076.

18. Kartal F, Janssen MHA, Hollmann F, et al. Improved esterification activity of Candida rugosa lipase in organic solvent by immobilization as Cross-linked enzyme aggregates (CLEAs). J Mol Catal B Enzym. 2011;71(3-4):85-89.

19. Mafra ACO, Bontorin M, Ulrich G, et al. Combined CLEAs of invertase and soy protein for economically feasible conversion of sucrose in a fedbatch reactor. Food Bioprod Process. 2018;110:145-157.

20. Karimpil JJ, Melo JS, D’Souza SF. Hen egg white as a feeder protein for lipase immobilization. J Mol Catal B Enzym. 2011;71(3-4):113-118.

21. Bio-Rad Laboratories. Bio-Rad protein assay. Bio-rad. 2010;1-24.

22. Mahmod SS, Yusof F, Jami MS, et al. Optimizing the preparation conditions and characterization of a stable and recyclable cross-linked enzyme aggregate (CLEA)-protease. Bioresour Bioprocess. 2016;3(1):3. 
23. Mahmod SS, Yusof F, Jami MS, et al. Development of an immobilized biocatalyst with lipase and protease activities as a multipurpose cross-linked enzyme aggregate (multi-CLEA). Process Biochem. 2015;50(12):2144-2157.

24. Tummalapalli M, Gupta B. A UV-Vis spectrophotometric method for the estimation of aldehyde groups in periodate-oxidized polysaccharides using 2,4-dinitrophenyl hydrazine. J Carbohydr Chem. 2015;34(6):338348.

25. Jadhav SB, Singhal RS. Screening of polysaccharides for preparation of \# -amylase conjugate to enhance stability and storage life. Carbohydr Polym. 2013;92(2):1724-1729.

26. Nadar SS, Rathod VK. Magnetic macromolecular cross linked enzyme aggregates (CLEAs) of glucoamylase. Enzyme Microb Technol. 2015;10(9):1-38

27. Khanahmadi S, Yusof F, Amid A, et al. Optimized preparation and characterization of CLEA-lipase from cocoa pod husk. $J$ Biotechnol. 2015;202:153-161.

28. Easa MN, Yusof F, Abd Halim A. Characterization of Cross-Linked Enzyme Aggregates (CLEA ) -amylase from Zophobas morio. Int Food Res J. 2017;24:335-9.

29. Schoevaart R, Wolbers MW, Golubovic M, et al. Preparation, optimization, and structures, of cross-linked enzyme aggregates (CLEAs). Biotechnol Bioeng. 2004;87(6):754-762.

30. Easa MN, Yusof F. Optimizing the preparation of cross-linked enzyme aggregates (CLEA) - amylase from supermeal worm (Zophobas Morio). ARPN J Eng Appl Sci. 2015;10(21):9710-9716.
31. Mardina V, Yusof F. Statistical optimization of physicochemical factors for protease production by bacillus licheniformis on skim latex serum fortified media. J Eng Sci Technol. 2015;1(6):45-52.

32. Safi NAAA Al, Yusof F. Immobilization of CLEA-LIPASE of Hevea brasiliensis onto Magnetic Nanoparticles for Enhanced Biocatalytic Performance. Malaysian Appl Biol J. 2020;49(1):141-152.

33. Sheldon RA, Van Pelt S. Enzyme immobilisation in biocatalysis: why, what and how. Chem Soc Rev. 2013;42(42):6223-6235.

34. Kim M, Park JM, Um HJ, et al. Immobilization of cross-linked lipase aggregates onto magnetic beads for enzymatic degradation of polycaprolactone. J Basic Microbiol. 2010;50(3):218-226.

35. Gupta A, Srivastava SK. Study of cross linked enzyme aggregate of glucose isomerase of Streptomyces thermonitrificans immoblised on magnetic particle. J Biochem Tech. 2017;7(2016):1102-6.

36. Talekar S, Nadar S, Joshi A, et al. Pectin cross-linked enzyme aggregates (pectin-CLEAs) of glucoamylase. RSC Advances. 2014;6:59444-59453.

37. Mohamad NR, Marzuki NHC, Buang NA, et al. An overview of technologies for immobilization of enzymes and surface analysis techniques for immobilized enzymes. Biotechnol Biotechnol Equip. 2015;29(2):205-220.

38. Otto TN, Habicht W, Dinjus E, et al. Catalyst Characterization with FESEM / EDX by the Example of Silver-Catalyzed. In: Kazmiruk DV, editor. Scanning Electrom Microscopy. Germany: In Tech; 2012. p. 367-392.

39. Sheldon RA. CLEAs, Combi-CLEAs and "Smart" Magnetic CLEAs: Biocatalysis in a Bio-Based Economy. Catalysts. 2019;9(261):1-31. 